\title{
Comparison of enzyme-linked immunosorbent assay, radioimmunoassay, complement fixation, anticomplement immunofluorescence and passive haemagglutination techniques for detecting cytomegalovirus IgG antibody
}

\author{
JC BOOTH, GILLIAN HANNINGTON, TMF BAKIR, H STERN, H KANGRO, \\ PD GRIFFITHS, RB HEATH
}

From the Department of Medical Microbiology, St George's Hospital Medical School, London SWI7 ORE and the Department of Virology, St Bartholomew's Hospital Medical School, London ECI

SUMMARY The radioimmunoassay (RIA) and enzyme-linked immunosorbent assay (ELISA) techniques were found to be comparable in sensitivity and specificity for detecting cytomegalovirus IgG antibody, and 10 to 100 times more sensitive than complement-fixation (CF), anticomplement immunofluorescence (ACIF) and passive haemagglutination (PHA). In screening tests for antibody, the frequency of false-positive and -negative results was $0.6 \%$ for RIA and ELISA, $1.5 \%$ for CF, $1.6 \%$ for ACIF and $3.6 \%$ for PHA. PHA was the least satisfactory test, largely because of technical problems.

Cytomegalovirus (CMV) infection is an important cause of congenital brain damage ${ }^{1}$ and is also a major complication of both prolonged immunosuppressive therapy, especially in patients with organ transplants, ${ }^{2}$ and multi-donor blood transfusions. ${ }^{3}$ For serological diagnosis of infection, as well as for screening for antibody in patients and in blood donors, the solid-phase indirect radioimmunoassay (RIA) ${ }^{4-6}$ and enzyme-linked immunosorbent assay (ELISA) ${ }^{7-9}$ techniques offer distinct improvements in sensitivity over previous methods. Although the principle of both tests, based on the detection of antigen-antibody reactions by means of a labelled anti-antibody, is the same, each possesses its own particular technical advantages and disadvantages, and both require their own expensive equipment for the reading of the results. There is still a lack of data on how they compare in sensitivity and specificity. The present study was undertaken to compare the two methods for the detection of CMV IgG and to evaluate them against the older techniques of complement-fixation (CF), passive haemagglutination (PHA) and anticomplement immunofluorescence (ACIF).

\section{Material and methods}

S E R A

These were collected from women attending the antenatal clinics of St Bartholomew's Hospital"1 and were stored at $-20^{\circ} \mathrm{C}$ until required for testing.

SEROLOGICAL TECHNIQUES

The RIA test was done as previously described.5 A

Accepted for publication 24 May 1982 virus-specific binding index ( $\mathrm{SBI}$ ) of $>2$ was taken to indicate the presence of virus-specific antibody and antibody titres were calculated graphically from the reciprocal of the serum dilution having an SBI of 2.0.

The ELISA test was done as previously reported. ${ }^{7}$ An $\mathrm{E} 400$ reading more than twice that obtained for a pool of known-negative sera was taken to indicate the presence of antibody; antibody titres were calculated graphically from the reciprocal of the serum dilution with an E400 reading of $0 \cdot 2$.

The results of ACIF and CF tests, and the methods 
used, have already been reported in detail elsewhere. ${ }^{10}$

The PHA technique was carried out by the method of Yeager ${ }^{12}$ with the same antigen preparations as in the ELISA test.

\section{Results}

COMPARISON OF SENSITIVITY

The relative sensitivities of the RIA, ELISA, ACIF, CF and PHA tests were examined by titrating 66 sera, previously found to be positive for CMV antibody by $\mathrm{CF}$. The various tests were done independently, and under code; the RIA, CF and ACIF tests at St Bartholomew's Hospital, the ELISA and PHA tests at St George's. The range of antibody titres for each test, and the geometric mean titres, are shown in Table 1. The RIA and ELISA tests were considerably more sensitive than the other three tests. Antibody

Table 1 Results of titration of 66 human sera for CMV antibody by five different methods.

\begin{tabular}{llc}
\hline Method & $\begin{array}{l}\text { Range of antibody titres } \\
\text { obtained }\end{array}$ & $\begin{array}{l}\text { Geometric mean } \\
\text { antibody titre }\end{array}$ \\
\hline ELISA & $3200-102400$ & 12139 \\
RIA & $1500-40000$ & 6584 \\
ACIF & $32-4096$ & 618 \\
PHA & $<8-2048$ & 145 \\
CF & $8-512$ & 59 \\
\hline
\end{tabular}

titres by ELISA were about twice those obtained by RIA, but both tests were 10-100 times more sensitive than ACIF, CF and PHA. One serum was found to be repeatedly negative by $\mathrm{PHA}$, although positive by the other tests (antibody titres by PHA $<8$, RIA 5600 , ELISA 3200, ACIF 256, CF 32).

Although there was no complete correlation in the levels of antibody detected by RIA and ELISA (sera having the same titre by one of the tests could show differences of up to 32-fold by the other) (Figure), the degree of correlation was highly significant $(\mathrm{p}<$ $0.001 ; r=0.55)$.

\section{SCREENING FOR ANTIBODY}

Three hundred and fifteen unselected sera were screened for CMV antibody under code, at a single dilution of $1 / 300$ by ELISA, $1 / 400$ by RIA, and $1 / 8$ by ACIF, PHA and CF. All the sera were examined in a single test by each method in turn. One hundred and ninety four sera $(61.6 \%)$ were positive for antibody by ELISA, $192(60.9 \%)$ by RIA and by ACIF, 191 $(60.6 \%)$ by CF, and only $167(53 \%)$ by PHA.

Excluding the PHA test, only 10 of the 315 sera (3.2\%) gave discordant results (Table 2). Six sera were positive by ELISA or RIA but consistently

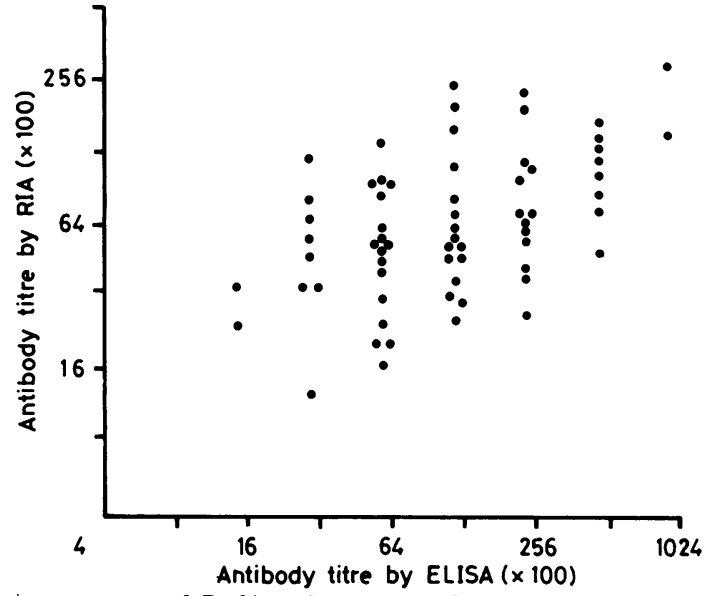

Comparison of CMV antibody titres obtained by ELISA and $R I A$.

negative by $\mathrm{ACIF}$ and $\mathrm{CF}$. Three of these were positive only by ELISA and one only by RIA. However, on retesting, two of the three sera previously ELISA-positive and the one serum previously RIApositive were now found to be negative. Repeat testing of the two sera previously positive by both RIA and ELISA confirmed their positive results. The remaining four discordant sera were consistently positive only by $\mathrm{ACIF}$ and/or CF. Ignoring the greater sensitivity of the ELISA and RIA techniques, these results give a maximum incidence of false readings of two of $315(0.6 \%)$ for both ELISA and RIA, six of $315(1.9 \%)$ for ACIF and five of $315(1.5 \%)$ for $\mathrm{CF}$, the numbers being equally divided between falsepositive and false-negative results.

On screening the 315 sera by PHA, at a single dilution of $1 / 8$, there were 27 discrepancies $(8.5 \%)$ when compared with ELISA; 26 were apparently false-negatives $(8.2 \%)$ and one serum $(0.3 \%)$ was positive by PHA but negative by ELISA. Some of the false-negative results were due to the agglutinated erythrocytes failing to settle properly and slipping to the bottom of the reaction well, giving the appearance of a negative pattern of haemagglutination.

Table 2 Discordant results obtained with 10 serum specimens examined for CMV antibody by ELISA, RIA, CF and $A C I F$.

\begin{tabular}{lllll}
\hline $\begin{array}{l}\text { Number of sera giving } \\
\text { discordant results }\end{array}$ & \multicolumn{4}{l}{ Positive or negative results by: } \\
\hline 2 & ELISA RIA & CF & ACIF \\
\hline 3 & + & + & - & - \\
1 & + & - & - & - \\
1 & - & + & - & - \\
1 & - & - & + & - \\
2 & - & - & + & + \\
\hline
\end{tabular}


When the 315 sera were titrated by PHA, 14 of the previously negative sera were now found to be positive at dilutions of $1 / 16$ and above. The one serum with the discrepant positive result had a titre of $<8$ on retesting. Thus, even after titrating the sera, the number of sero-positives by PHA was less than by the other methods, that is, $180(57 \cdot 1 \%)$, and there were 12 discrepancies $(3.6 \%)$, all false negatives, against RIA and ELISA.

\section{Discussion}

ELISA and RIA were found to be comparable in sensitivity for detecting IgG antibody to CMV and were some 10-100 times more sensitive than $C F$, ACIF and PHA. This confirms previous studies in which ELISA and RIA were separately found to give 4 to 500 times higher antibody titres than these other methods. ${ }^{7}{ }^{13-16}$ ELISA titres were on average twice as high as RIA and this was almost certainly due to the differences in the temperature and duration of the initial period of incubation - namely, $4^{\circ} \mathrm{C}$ for $18 \mathrm{~h}$ for ELISA and $37^{\circ} \mathrm{C}$ for $1 \mathrm{~h}$ for RIA. In fact, the antibody titres by RIA can be increased two to four times by incubating at $37^{\circ} \mathrm{C}$ for $2 \mathrm{~h}$ (H Kangro, unpublishèd observations).

However, in the screening tests for CMV antibody, there were remarkably few discrepancies between the various methods, except in the case of PHA. These ranged from $0.6 \%$ for RIA and ELISA to $1.9 \%$ for ACIF. The low incidence of discrepancies in the CF test $(1.5 \%)$, when compared with ELISA and RIA, contrasts with the frequent statements in the literature that the CF test has low sensitivity for detecting CMV antibody. The preparation of potent high-titred antigen, by alkaline glycine buffer extraction and ultrasonication of infected cells, is obviously important for reliable results in the CF test.

The PHA test is by far the simplest of the various techniques but, despite the improvements in the technique recommended by Yeager, ${ }^{12}$ and the findings of others that PHA is at least as sensitive as $\mathrm{CF}, 1718$ antibody titres in the present study were relatively low and the number of discrepant, falsenegative results was high. This is undoubtedly due partly to technical problems in obtaining stable settling patterns of the sensitised erythrocytes. However, it is possible that there may also be differences in the range and distribution of viral antigens that attach to the red cell surface and to the surface of microtitre wells.

ELISA and RIA appear to differ only marginally in sensitivity and specificity, in tests for CMV IgG antibody. The advantage of ELISA is the stability of the enzyme label but there are some problems in handling large numbers of sera in any given test because of the need to control the substrate reaction. RIA tests require special facilities for the handling and disposal of radioactivity but there are fewer steps involved in the test than with ELISA. Which technique to use for diagnostic purposes must depend on the facilities and preferences of the individual laboratory.

\section{References}

I Stern H. Cytomegalovirus infection in the neonate and its prevention. Postgrad Med J 1977;53:588-91.

2 Ho M. Virus infections after transplantation in man, Arch Virol 1977;55:1-24.

${ }^{3}$ Lang DJ. Cytomegalovirus infections in organ transplantation and post transfusion. Arch Ges Virusforsch 1972;37:365-77.

${ }^{4}$ Knez V, Stewart JA, Ziegler DW. Cytomegalovirus specific IgM and IgG response in humans studied by radioimmunoassay. $J$ Immunol 1976;117:2006-13.

${ }^{5}$ Kangro HO. Evaluation of a radioimmunoassay for IgM-class antibodies against cytomegalovirus. Br J Exp Pathol 1980;61: 512-20.

6 Jankowski MA, Gut W, Nawrocka E, Kantoch M. Detection and differentiation of cytomegalovirus antibodies by radioimmunoassay. J Virol Methods 1980;1:133-8.

${ }^{7}$ Booth JC, Hannington G, Aziz TAG, Stern H. Comparison of enzyme-linked immunosorbent assay (ELISA) technique and complement-fixation test for estimation of cytomegalovirus IgG antibody. J Clin Pathol 1979;32:122-7.

8 Van Loon A, Van Der Logt JThM, Van Der Veen J. Enzymelinked immunosorbent assay for measurement of antibody against cytomegalovirus and rubella virus in a single serum dilution. J Clin Pathol 1981;34:665-9.

${ }^{9}$ Sarov I, Andersen P, Andersen HK. Enzyme-linked immunosorbent assay (ELISA) for determination of IgG antibodies to human cytomegalovirus. Acta Pathol Microbiol Scand [B] 1980; 88:1-9.

${ }^{10}$ Griffiths PD, Buie KJ, Heath RB. A comparison of complement fixation, indirect immunofluorescence for viral late antigen and anti-complement immunofluorescence for the detection of cytomegalovirus specific serum antibodies. J Clin Pathol 1978;31: 827-31.

11 Kangro HO, Pattison JR, Heath RB. The detection of rubellaspecific IgM antibodies by radioimmunoassay. Br J Exp Pathol 1978;59:577-83.

12 Yeager AS. Improved indirect haemagglutination test for cytomegalovirus using human $\mathrm{O}$ erythrocytes in lysine. J Clin Microbiol 1979;10:64-8.

${ }^{13}$ Forghani B, Schmidt NJ, Lennette EH. Antisera to human cytomegalovirus produced in hamsters: reactivity in radioimmunoassay and other antibody assay systems. Infect Immunol 1976; 14:1184-90.

14 Castellano GA, Hazzard GT, Madden DL, Sever JL. Comparison of the enzyme-linked immunosorbent assay and the indirect haemagglutination-inhibition test for detection of antibody to cytomegalovirus. J Infect Dis 1977;136 suppl: 337-40.

is Cappel R, De Cuyper F, De Braekeleer J. Rapid detection of IgG and IgM antibodies for cytomegalovirus by the enzyme-linked immunosorbent assay (ELISA). Arch Virol 1978;58:253-8.

${ }^{16}$ Krishna RV, Meurman OH, Ziegler T, Krech UH. Solid-phase enzyme immunoassay for determination of antibodies to cytomegalovirus. J Clin Microbiol 1980;12:46-51.

17 Bernstein MT, Stewart JA. Indirect haemagglutination test for detection of antibodies to cytomegalovirus. Appl Microbiol 1971;21:84-9. 
${ }^{18}$ Cremer NE, Hoffman M, Lennette EH. Analysis of antibody assay methods and classes of viral antibodies in serodiagnosis of cytomegalovirus infection. J Clin Microbiol 1978;8:153-9.
Requests for reprints to: Dr JC Booth, Department of Medical Microbiology. St George's Hospital Medical School. Cranmer Terrace. London SW17 ORE. England. 